Témoigner Témoigner. Entre histoire et mémoire

Getuigen Revue pluridisciplinaire de la Fondation Auschwitz

$123 \mid 2016$

Traduire le témoignage

\title{
Christopher Clark. IJzeren Koninkrijk. Opkomst en ondergang van Pruisen 1600-1947
}

Vertaald uit het Engels door Wil Hansen, Amsterdam: De Bezige Bij, 2015

\section{Brecht Capiau}

\section{OpenEdition}

Journals

\section{Édition électronique}

URL : https://journals.openedition.org/temoigner/5545

DOI : $10.4000 /$ temoigner.5545

ISSN : 2506-6390

Éditeur :

Éditions du Centre d'études et de documentation Mémoire d'Auschwitz, Éditions Kimé

Édition imprimée

Date de publication : 1 octobre 2016

Pagination : 192-193

ISBN : 987 2-9600926-4-6

ISSN : 2031-4183

Référence électronique

Brecht Capiau, «Christopher Clark. IJzeren Koninkrijk. Opkomst en ondergang van Pruisen 1600-1947»,

Témoigner. Entre histoire et mémoire [Online], 123 | 2016, Online op 02 novembre 2021, geraadpleegd op 04 novembre 2021. URL: http://journals.openedition.org/temoigner/5545 ; DOI: https://doi.org/

10.4000/temoigner.5545

Ce document a été généré automatiquement le 4 novembre 2021.

Tous droits réservés 


\section{Christopher Clark. IJzeren Koninkrijk. Opkomst en ondergang van Pruisen}

\section{0-1947}

Vertaald uit het Engels door Wil Hansen, Amsterdam: De Bezige Bij, 2015

\section{Brecht Capiau}

\section{RÉFÉRENCE}

Christopher Clark. IJzeren Koninkrijk. Opkomst en ondergang van Pruisen 1600-1947. Vertaald uit het Engels door Wil Hansen, Amsterdam: De Bezige Bij, 2015, 850 p.

1 'Het hart van Duitsland is Pruisen. Daar ligt de oorzaak van de pest die steeds weer de kop opsteekt.' Deze uitspraak van Winston Churchill in het Britse parlement op 21 september 1943 vertolkte perfect de gevoelens van de geallieerden ten opzichte van Pruisen. Amper vier jaar later werd de staat dan ook opgeheven en vakkundig uit de geschiedenisboeken gewist. Wie de groen-witte cover van Clarks boek bekijkt, ziet in eerste instantie weinig redenen om de gespierde taal van Churchill in twijfel te trekken. We zien de Pickelhaube, de typisch Pruisische pinhelm, met daarop de adelaar die stoer en ongenaakbaar de scepter en de rijksappel tussen de klauwen klemt. Het imago van Pruisen als efficiënte, maar oorlogszuchtige en militaire staat lijkt bevestigd.

De Australische historicus Christopher Clark gebruikt dit stereotiepe beeld om er een meer genuanceerd verhaal over Pruisen aan op te hangen. Clark begint zijn zeventien hoofdstukken tellende betoog in 1417 met de aankoop van Brandenburg, een gebied waar ook de huidige Duitse hoofdstad Berlijn toe behoort. Hoewel het toen militair, economisch, agrarisch en geografisch weinig voorstelde, was het van essentieel belang voor de Zuid-Duitse familie Hohenzollern. Nadat ze de titel van keurvorst hadden verkregen, manoeuvreerde deze familie met behulp van een omzichtig en vaak opportunistisch beleid zich naar de top van de Europese politiek. Voor een minder gesofisticeerd schrijver is dit de ideale aanleiding om over te gaan tot een oplijsting van 
alle keurvorsten die Brandenburg rijk is geweest, inclusief saillante details. Clark gaat echter niet voor deze gemakkelijkheidsoplossing en neemt ruimschoots de tijd om de keurvorsten te duiden in hun respectieve tijdscontext. Hij vraagt hierbij een duidelijke inspanning van zijn lezer. De academicus onderbreekt immers regelmatig zijn betoog en duikt in het verleden of zelfs in de toekomst om zijn punt te maken. De rode draad is echter steeds dat Pruisen zich tussen hamer en aanbeeld bevond en voortdurend op zijn hoede moest zijn voor grote mogendheden zoals Rusland en Frankrijk. Over hun plaats binnen het Habsburgse keizerrijk bleven de Pruisen bewust ambigu. Enerzijds is er rebelse wrevel jegens de keizer, anderzijds is er het nodige respect voor de aloude instellingen van de Habsburgers. Defensief als het moest, offensief als het kon, mag je daarom gerust als motto van de staat Pruisen beschouwen.

3 Soms lijkt Clark meer op een politiek wetenschapper dan op een historicus. Zo besteedt hij bijzonder veel aandacht aan de vorming en de samenstelling van de diverse regeringen en de conflicten die hieruit zijn ontstaan. Wellicht een taaie brok voor de doorsnee lezer, maar even goed een verademing in vergelijking met veel populairwetenschappelijke werken die de zaken soms iets te eenvoudig voorstellen. De militaire staat van dienst van de Pruisen behandelt de historicus, wat de individuele veldslagen betreft, op een onevenwichtige manier. De Slag bij Leipzig in 1813 wordt bijvoorbeeld uitgebreid in zijn context geplaatst en belicht, terwijl het aandeel van de Pruisen tijdens de Slag bij Waterloo in enkele bladzijden wordt afgehandeld. Clark kiest ervoor om te focussen op de redenen voor het militaire succes, veeleer dan op de militaire manoeuvres. Dat wil echter niet zeggen dat Pruisen een door en door gemilitariseerde staat was met weinig bewegingsvrijheid. Zo werden er aan het einde van de achttiende eeuw vier bladen uitgegeven die de Franse revolutie als een historische noodzaak beschouwden. In een tijd waarin elke natie vreesde dat de revolutie geëxporteerd zou worden naar hun streek, is de houding van de Pruisische staat op zijn minst opmerkelijk te noemen, argumenteert Clark. Pruisen kende wel degelijk hervormers die op tijd en stond de staat kritisch onder de loep namen en een significante bijdrage leverden aan de ontwikkeling ervan. Filosofen als Hegel en Wilhelm von Humboldt, maar ook staatslui als Frederik De Grote en Otto von Bismarck leverden de broodnodige zuurstof wanneer de staat Pruisen in de touwen hing. Ondanks de Duitse eenmaking in 1871 op instigatie van Bismarck, bleef Pruisen een vreemdeling binnen Duitsland. De staat is er nooit in geslaagd om een gemeenschappelijke identiteit onder zijn inwoners te ontwikkelen, concludeert Clark. Voor de doorsnee 'Pruis' bleef het vaderland een vreemde, abstracte entiteit waar hij weinig voeling mee had. Wanneer in 1876 het Duits als officiële taal in Pruisen wordt ingevoerd om het tij te doen keren, is het eigenlijk al veel te laat.

De vraag of er een verband bestaat tussen de nazi's en Pruisen is volgens Clark complexer dan men denkt. Een teleologisch perspectief, als zou nazi-Duitsland het eindpunt zijn van de Pruisische politiek, wijst de academicus resoluut van de hand. Hitler mag dan wel gefascineerd zijn geweest door Bismarck en Frederik de Grote, de aanslag op de Führer op 20 juli 1944 door overwegend Pruisische officieren toont aan dat de liefde niet wederzijds was. De nazipropaganda die inhaakte op het roemrijke Pruisische verleden en de dubieuze houding van rijkspresident von Hindenburg tegenover de nazi's maakten het onmogelijk om nog enig respect te koesteren voor de Pruisen. 
5 Clark is een bijzonder erudiet schrijver die in dit boek moeiteloos het politieke kan afwisselen met het anekdotische. Zo toont hij Pruisen met een menselijker gelaat dan doorgaans het geval is. Hoewel dit boek al in 2007 verscheen en tal van prijzen won, moesten wij tot 2015 wachten op een vertaling. Wie niet genoeg krijgt van Pruisen kan zich bovendien tegoed doen aan de bijna honderd bladzijden voetnoten die dit monumentale werk telt. 